\title{
An Evaluation Study of Efficiency of Microfinance Institutions in Yemen
}

\author{
Dr. Eissa Hasan AboHulaika \\ Assistant Professor, Faculty of Humanitarian and Administrative Sciences \\ Department of Financial Sciences \& Banking, Al-Razi University, Sana'a, Yemen \\ Tel: 967-772-156-744Ｅ-mail: abuholika@gmail.com
}

Received: November 18, 2018 Accepted: December 17, 2018 Published: December 20, 2018

doi:10.5296/wjbm.v4i2.14087

URL: https://doi.org/10.5296/wjbm.v4i2.14087

\begin{abstract}
This paper is intended to evaluate the efficiency of microfinance institutions in Yemen in terms of loan officer productivity and operational self-sufficiency. This study is based on empirical method. The population of this study were 11 Microfinance Institutions operating in Yemen. The data collected was based on both primary and secondary data. The primary data was collected using questionnaire, open-end interviews, while the secondary data was collected from books, Microfinance Institutions Websites, annual reports, Social Fund for Development (SFD) annual reports, Yemen Microfinance Network (YMN), etc. The main findings of the study were that most microfinance institutions in Yemen are inefficient in terms of loan officer productivity and operational self-sufficiency. The study presented valuable recommendations and suggestions based on the findings of the study to strengthen, enhance \& improve the efficiency of microfinance institutions in Yemen.
\end{abstract}

Keywords: Evaluation, Microfinance, Microfinance Institutions, Efficiency 


\section{Introduction}

Microfinance has gained a universal recognition as an important tool for reducing poverty in many developing countries. Performance concept relating to MFIs is a vital and crucial issue for many reasons such as: to ensure donors or/investors effective and efficient utilization of billions of dollars invested in MF programs also help regulators in controlling and monitoring the MFIs, stating that inefficient MFIs represents a main constraint on the development of the microfinance industry. Therefore, performance evaluation is a good tool for managing MFIs and is a requirement for achieving sustainability, outreach, efficient, and effective utilization of the resources.

Microfinance institutions are considered as an effective tool for achieving the objective of financial inclusion. To achieve this objective it is necessitate that MFIs should be sustainable while reaching the poorest of poor. Microfinance is also considered as an innovative tool for enabling the poor to reap the benefit of growth. In recent past, it has emerged as an effective tool for achieving the mission of financial inclusion in the developing countries. This study is intended to assess the performance evaluation of Micro Finance Institutions in Yemen relating to efficiency.

Armendáriz and Labie, (2011) mentioned that microfinance concept emerged in 1970s in the form of microcredit provision, but then and namely in the last decade many of microfinance institutions (MFIs) began expanding their financial services like saving, money transfer, insurance, technical and training support for MSEs as well as the poor.

The recent evolution of the microfinance sector can be viewed in terms of the rapid growth in the number of active MFIs, increases in the volume of business they conduct, a broader range of financial services on offer, and changes in the types and motivations of MFIs. In this latter respect, an important marker in the sector's evolution is the arrival of profit - oriented MFIs. Although lauded by many as critically - important for the maturation of the sector, these MFIs also ushered in debates about whether it is possible to effectively blend nonprofit ideals and for - profit orientations and practices Morduch, (2000).

The fact that Microfinance Institutions (MFIs) tend not to operate in the same way as traditional banks does not mean that they are not interested in profitability and efficiency issues. However, existing tools to assess the performance of traditional banking institutions may not be appropriate within this new context. How can we assess if a MFI is efficient? How should we compare MFIs? How far is existing knowledge on traditional financial institutions appropriate in order to understand the behavior of MFIs? These are the issues that are addressed in this research.

The main objective of this study is to evaluate the efficiency of microfinance institutions in Yemen in terms of loan officer productivity and operational self-Sufficiency. The study is based on empirical method. The data was collected from both primary and secondary data. The primary data was collected through questionnaire, open-end interviews, while the secondary data was collected from Microfinance Institutions Websites, Annual Reports, Social Fund for development (SFD), Yemen Microfinance Network (YMN), etc. The 
population of this study were 11 Microfinance Institutions in Yemen. The main findings of this study were that Microfinance Institutions in Yemen are less efficient in terms of loan officer productivity and operational self-sufficiency.

The efficiency refers to the ability to produce maximum output at a given level of input, and it is the most effective way of delivering small loans to the very poor in microfinance context Woller (2000). This involves cost minimization and income maximization at a given level of operation, and it has an enduring impact on financial sustainability of microfinance institutions. Thus, efficiency can be measured by its productivity (for instance, number of borrowers per staff) and cost management (for instance, cost per borrower) dimensions. Later Woller and Schreiner (2002) examined the determinants of financial sustainability and it was found that productivity was significant determinant of profitability. Moreover, a recent study by Ganka (2010) on Tanzanian rural microfinance found a negative and strongly statistically significant relationship between number of borrowers per staff and financial sustainability. He justified that microfinance staff for rural MFIs are not efficient as a result they fail to manage borrowers when their number grows causing microfinance institutions' un-sustainability.

In this study the researcher evaluates the efficiency of microfinance institutions in Yemen with regard loan officer productivity and operational Self-Sufficiency based on the Philippine Microfinance Standards, (2007).

\section{A) Loan Officer Productivity}

Loan officers are the prime revenue generators of MFIs. Most MFIs try to focus on the productivity of the loan officers in order to improve the overall productivity of the MFI.

\section{B) Operational Self-Sufficiency}

Indicates whether or not enough revenues are earned to fully cover the costs of the microfinance operations.

Table 1. Profile of microfinance institution in Yemen

\begin{tabular}{|c|c|c|c|c|c|c|c|}
\hline \multirow{3}{*}{$\begin{array}{c}\text { MF } \\
\text { Category }\end{array}$} & \multirow{3}{*}{ Institution } & \multirow{3}{*}{ Est. } & \multirow{3}{*}{ Branches } & \multicolumn{3}{|c|}{ Active Number of Clients } & \multirow{3}{*}{$\begin{array}{c}\text { Outstanding } \\
\text { Loan Portfolio } \\
\text { Million YR }\end{array}$} \\
\hline & & & & \multicolumn{2}{|c|}{ Borrowers } & \multirow{2}{*}{ Savers } & \\
\hline & & & & Total & Women $(\%)$ & & \\
\hline \multirow[t]{4}{*}{ Banks } & $\begin{array}{l}\text { Al-Amal } \\
\text { Microfinance Bank }\end{array}$ & $\begin{array}{c}\text { 2002, actual } \\
\text { operation } 2009\end{array}$ & 17 & 26,154 & 59.8 & 44,336 & 956 \\
\hline & $\begin{array}{l}\text { Al-kuraimi Islamic } \\
\text { Microfinance Bank }\end{array}$ & 2010 & 78 & 1,829 & 2 & 39,794 & 559 \\
\hline & Tadhamon Bank & 2006 & 11 & 5,437 & 44 & 0 & 732 \\
\hline & Total of banks & & 106 & 33,420 & & 84,130 & 2,247 \\
\hline \multirow[t]{3}{*}{ Foundations } & $\begin{array}{l}\text { National MF } \\
\text { Foundation }\end{array}$ & 2003 & 11 & 12,791 & 91 & 20,239 & 471 \\
\hline & Aden MF Foundation & 2005 & 4 & 6,666 & 96 & 9,577 & 299 \\
\hline & Social Institution for & 2006 & 1 & 1,472 & 87 & 0 & 166 \\
\hline
\end{tabular}




\begin{tabular}{|c|c|c|c|c|c|c|c|}
\hline & \begin{tabular}{|l|} 
Sustainable \\
Development (SFSD)
\end{tabular} & & & & & & \\
\hline & Total & & 16 & 20,929 & & 29,816 & 936 \\
\hline \multirow[t]{5}{*}{ programs } & $\begin{array}{l}\text { Abyan for Saving and } \\
\text { Credit Program }\end{array}$ & 2003 & 1 & 7,926 & 96 & 8,000 & 252 \\
\hline & $\begin{array}{l}\text { Nama' MF } \\
\text { Development Program }\end{array}$ & 2000 & 6 & 7,160 & 35 & 1,682 & 363 \\
\hline & Sana'a MF - Azal & 2001 & 3 & 4,927 & 55 & 2,718 & 344 \\
\hline & WadiHadhramaut & 2000 & 1 & 1,618 & 32 & 3,118 & 93 \\
\hline & Total \# of Programs & & 11 & 21,631 & & 15,518 & 1,052 \\
\hline company & $\begin{array}{l}\text { Al-Awa'el MF } \\
\text { Company }\end{array}$ & 2000 & 3 & 3,224 & 85 & 0 & 91 \\
\hline Fund & $\begin{array}{l}\text { Small Enterprise } \\
\text { Development Fund } \\
(\text { SEDF })\end{array}$ & 2002 & 7 & 3,002 & 19 & 0 & 1,520 \\
\hline total & & & 143 & 82,206 & & 129,464 & 5,846 \\
\hline
\end{tabular}

Source: SFD, (2013, p. 84).

It is observed in the above Table that the total number of borrowers are 82,206 and the total number of savers are 129,464 and the total outstanding loan portfolio in Million is YR. 5,846 as mentioned in Social Fund for Development, Annual Report (2013)

Table 2. SEEP REPORT, (2014) profile of micro finance institutions in Yemen

\begin{tabular}{|c|c|c|c|c|c|c|c|c|}
\hline \multirow{2}{*}{$\begin{array}{l}\text { Microfinance } \\
\text { Institutions }\end{array}$} & \multirow{2}{*}{$\begin{array}{c}\text { Active } \\
\text { Borrowers }\end{array}$} & \multirow{2}{*}{$\begin{array}{c}\text { Female } \\
\%\end{array}$} & \multirow{2}{*}{$\begin{array}{l}\text { Outstanding } \\
\text { Loan Portfolio } \\
\text { (Million) }\end{array}$} & \multicolumn{3}{|c|}{ Rates } & \multicolumn{2}{|c|}{$\begin{array}{l}\text { Cumulative Numbers from } \\
\text { beg. of } 2013\end{array}$} \\
\hline & & & & PAR \% & OSS \% & FSS \% & $\begin{array}{c}\text { No of Loans } \\
\text { Disbursed }\end{array}$ & $\begin{array}{c}\text { Value of Loans } \\
\text { Disbursed } \\
\end{array}$ \\
\hline $\begin{array}{c}\text { Al-Amal Microfinance } \\
\text { Bank }\end{array}$ & 35,318 & $46 \%$ & 2,140 & $0.60 \%$ & $100 \%$ & $56 \%$ & 7,258 & 736 \\
\hline $\begin{array}{c}\text { National Microfinance } \\
\text { Foundation }\end{array}$ & 15,635 & $92 \%$ & 644 & $3.95 \%$ & $133 \%$ & $90 \%$ & 4,131 & 320 \\
\hline $\begin{array}{c}\text { Nama Microfinance } \\
\text { Program }\end{array}$ & 9,314 & $39 \%$ & 587 & $3.07 \%$ & $133 \%$ & $103 \%$ & 2,824 & 323 \\
\hline $\begin{array}{c}\text { Aden Microfinance } \\
\text { Foundation } \\
\end{array}$ & 10,832 & $96 \%$ & 674 & $0 . \%$ & $231 \%$ & $136 \%$ & 2,691 & 276 \\
\hline $\begin{array}{c}\text { Al-Thadhamon } \\
\text { International Islamic } \\
\text { Bank }\end{array}$ & 8,787 & $37 \%$ & 1,433 & $1.10 \%$ & $116 \%$ & $116 \%$ & 8,631 & 2,105 \\
\hline $\begin{array}{c}\text { Al-Awael Microfinance } \\
\text { Company }\end{array}$ & 1,604 & $81 \%$ & 47 & $22.24 \%$ & $88 \%$ & $55 \%$ & 255 & 24 \\
\hline $\begin{array}{l}\text { Azal Microfinance } \\
\text { Program }\end{array}$ & 4,668 & $62 \%$ & 355 & $6.05 \%$ & $117 \%$ & $78 \%$ & 986 & 162 \\
\hline $\begin{array}{c}\text { Wadi Hadramaut Credit } \\
\text { Program }\end{array}$ & 3,651 & $36 \%$ & 467 & $10.32 \%$ & $147 \%$ & $118 \%$ & 1,709 & 267 \\
\hline $\begin{array}{l}\text { Al-Kuraimi Islamic } \\
\text { Microfinance Bank }\end{array}$ & 7,023 & $3 \%$ & 2137 & $0.33 \%$ & $84 \%$ & $84 \%$ & 2008 & 919 \\
\hline Total & 96,832 & & 8,484 & & & & 30,493 & 5,132 \\
\hline
\end{tabular}

Source: SEEP REPORT (2014, p. 1). 
It is observed in the above table that the total active borrowers were 96,832, the total number of loans disbursed were 30,493. It is also noticed that Al-Awael Micro finance Company has the highest Portfolio at Risk 22.24\%.

\section{Review of Literature}

Nawaz (2010) Paper entitled "Efficiency and Productivity of Microfinance: Incorporating the Role of Subsidies." At the outset of this paper, the writer endeavored to resolve few key issues. How to incorporate the subsidies into the non-parametric DEA framework to investigate the efficiency of microfinance institutions? What factors are important in determining the efficiency of microfinance and how much of these factors are driven by the subsidies in determining the efficiency of MFIs? In other words, how efficiency relates to the various organizational and structural variables amid the presence of subsidies? The way subsidy has been calculated in this paper i.e. social cost of subsidized MFIs, allows us to successfully enter the positive subsidies as an input and negative subsidies as an output in to the DEA efficiency specifications on the premise that the former distort public wealth while the later creates it. A comparison of efficiency scores with and without subsidies for various specifications reveals important information.

In particular, the message is very clear for those socially driven MFIs with outreach to women borrowers, to devise new income enhancing and enterprise development schemes which can go a long way in enhancing efficiency without subsidies. From private investor's perspective, it identifies those MFIs which are successful in achieving maximum efficiency by a proper mix of inputs and outputs. Even the social investors can benefit by analyzing mission-driven MFIs in the sample which have successful in increasing their outreach.

Nghiem et al. (2007) paper entitled "The Efficiency of Microfinance Institutions in Vietnam: Evidence from NGO Schemes in The North and the Central Regions." This paper stated that microfinance services in Vietnam are delivered by three types of providers, informal, semi-formal and formal service providers.

The data in this study include financial and operational information of 44 microfinance schemes operated in the north and the central of Vietnam. This paper has analyzed the efficiency of microfinance schemes in the north and the central regions of Vietnam using DEA technique. The study follows the production approach to measure the efficiency of microfinance schemes. The average technical efficiency scores of schemes surveyed is $76 \%$. For this consistency comparison, the study also uses the SFA and PLP techniques. The average technical efficiency scores estimated by SFA and PLP are $69 \%$ and $78 \%$, respectively. The rank correlation coefficients also confirm that three estimation techniques consistently rank the microfinance schemes.

Among environmental factors, maturity of schemes and distance to township are significantly influence the efficiency of schemes. However, it is against the expectation that schemes 
become efficient as they become more mature. In addition, schemes operate in remove area seem to be more efficient than other schemes.

Study done by Qayyum and Ahmad (n. d.) entitled "Efficiency and Sustainability of Micro Finance, Institutions in South Asia." The objective of this study has been to estimate the efficiency and sustainability of microfinance institution working in the South Asian countries such as Bangladesh, Pakistan and India. For the efficiency analysis we used non parametric Data Envelopment Analysis. We considered both inputs oriented and output oriented methods by assuming constant returns to scale and variable returns to scale technologies.

The results show that 53 MFIs (i.e., 60\%) out of 85 are operating at increasing returns to scale. The results further suggest that most of the MFIs experiencing IRS are in Bangladesh. Seven MFIs operate under decreasing returns to scale comprising five from Pakistan and two from India.

While conducting DEA analysis using single country data we found that eight MFIs from Pakistan, six MFIs from Bangladesh and five MFIs from India are at the efficient frontier under variable returns to scale. The technical efficiency figures for Pakistan, Bangladesh and India are $0.395,0.087$, and 0.28 , respectively, while average pure technical efficiencies for these countries respectively range between $0.713-0.823,0.175-0.547$ and $0.413-0.452$.

Hermes et al. paper entitled "Outreach and Efficiency of Microfinance Institutions." This paper has used SFA to examine whether there is a trade-off between outreach to the poor and efficiency of MFIs. Using a sample of more than 1,300 observations, we find convincing evidence that outreach is negatively related to efficiency of MFIs. More specifically, we find that MFIs that have lower average loan balances, which is a measure of the depth of outreach, are also less efficient. Moreover, we find evidence showing that MFIs that have more women borrowers as clients - again a measure of the depth of outreach - are less efficient. These results remain robustly significant after having added a long list of control variables. In view of the current move to commercialization of the microfinance industry this appears to be bad news. Commercialization may induce a stronger emphasis on efficiency.

Our study suggests that improving efficiency may only be achieved if MFIs focus less on the poor. It should be noted, however, that our results do not necessarily imply that a stronger focus on efficiency is bad for poverty reduction. This assumes that these efficient MFIs are able to contribute to improving economic conditions at the local, regional and country level, and that these contributions ultimately are higher than the contributions to poverty alleviation made by MFI concentrating on outreach rather than efficiency. To the best of our knowledge, until now no study has empirically investigated the existence (let alone the size) of the effects of increased efficiency of MFIs at the regional or macro (country) level. Further research is needed to look into this issue more carefully. One final note with respect to the current process of commercialization of microfinance is that commercialization does not necessarily mean more focus on efficiency. Commercial parties may have different aims when investing in MFI. 


\section{I Macrothink}

\section{Statement of the Problem}

Microfinance Institutions are essential ingredients in the development processes of a nation as they could have positive impact in reducing poverty, promoting micro enterprises, and women empowerment. In developing countries, including Yemen, MFIs emerged with unique opportunity to poor people who do not have access to commercial Banks.

Microfinance industry started in Yemen in 1997 by the Social Fund for Development, which piloted 5 microfinance programs in rural areas. The first program was in Al-Hodieda city, which started its operations in January 1998. A new phase began in 2000 by establishing strong urban programs with the idea that they could branch out into rural areas. Currently, there are about 14 MFIs operating in the whole country.

So far, various studies have been done in Yemen concerning microfinance. However, most of them are Al-Eryani (2002), Timothy et al. (2005), Al-Zamzami, (2005), Al-Tamimi (2007), Burjorjee and Jennings (2008), Qatinah (2013), AlHaidi, (2009).

In spite of the growth of MFIs in Yemen but the performance of microfinance institutions is a question to the researcher. Therefore the researcher through this study would like to evaluate the efficiency of MFIs in Yemen in terms of loan officer productivity and Operational self-Sufficiency.

\section{Significance of the Study}

Microfinance has gained a universal recognition as an important tool for reducing poverty in many developing countries. Performance concept relating to MFIs is a vital and crucial issue for many reasons such as: to ensure donors or/ investors effective and efficient utilization of billions of dollars invested in MF programs also help regulators in controlling and monitoring the MFIs, stating that inefficient MFIs represents a main constraint on the development of the microfinance industry. Therefore, performance evaluation is a good tool for managing MFIs and is a requirement for achieving sustainability, outreach, efficient, and effective utilization of the resources

This study is intended to assess the performance of Micro Finance Institutions in Yemen relating to efficiency. The findings of the study would help policy makers to support MFIs, which in return would create employment for the youth and also equip them with modern infrastructure. Furthermore, this study would help target groups to have solution to some of the problems facing MFIs in Yemen. With the concerted efforts of all the microfinance institutions, banks, government officials, concerning authorities, MSEs Promoters, Non-Governmental Organizations (NGOs), Investors, etc., the researcher hope that the fortune of MSEs in Yemen would dramatically improve. 


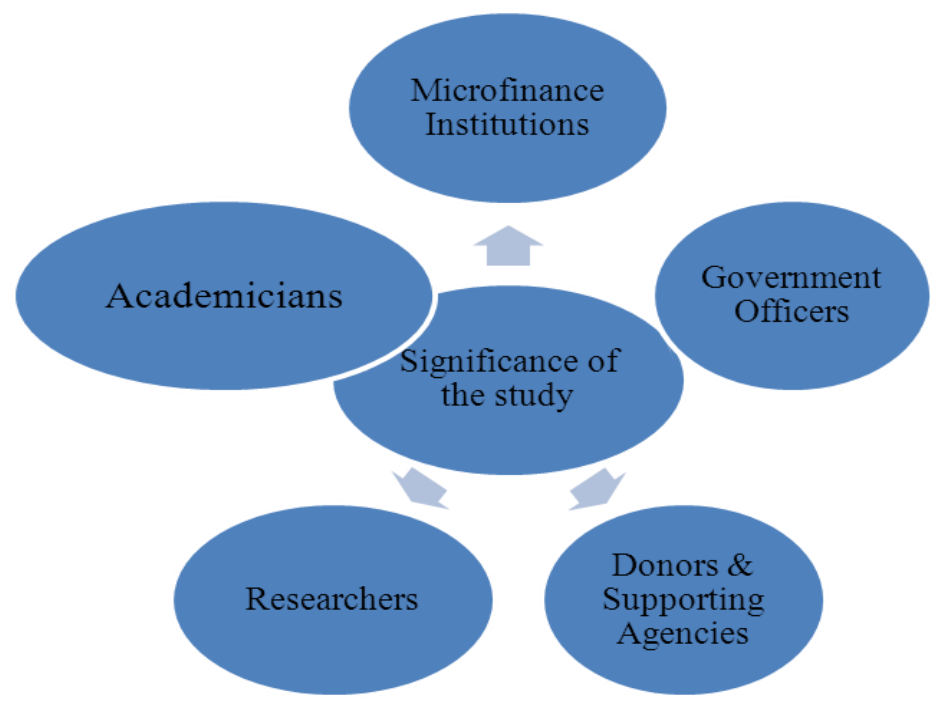

Figure 1. Significance of the study

The above figure shows the importance of the study for the microfinance institutions, donors and supporting agencies, researchers and academicians, etc.

\section{Scope of the Study}

The scope of this study is covered 11 MFIs registered in the Yemen Microfinance Network (YMN) such as Sana'a Microfinance Program(Azal), Al-Amal Microfinance Bank, Small and Micro Enterprise Development Unit affiliated to the Social Fund for Development, Saba Islamic Bank, Al-Kuraimi Islamic Microfinance Bank, Al-Tadhamon Small and Microfinance program, and Wadi Hadhramaut Microfinance program. Thus, the study covered 11 MFIs in 4 governorates (Al-Amanah, Sana'a, Aden, and Hadramaut) which represent 78 percent of all microfinance institutions operating in the country. The study evaluates the performance of MFIs in terms of efficiency.

\section{Objectives of the Study}

The overall objective of this research is to evaluate the overall performance of MFIs in terms of efficiency. The main objectives of this study are as follows:

1) To evaluate the efficiency of Microfinance institutions in Yemen in terms of Loan Officer Productivity.

2) To evaluate the efficiency of Microfinance institutions in Yemen in terms of Operational Self-Sufficiency.

3) To recommend, based on the findings, the most appropriate ways in order to enhance and improve the performance of the MFIs in Yemen.

\section{Hypotheses of the Study}

In line with the objectives stated above, the following hypotheses are formulated 


\section{$\Lambda$ Macrothink}

World Journal of Business and Management

ISSN 2377-4622

2018, Vol. 4, No. 2

and tested using Philippine Microfinance Standards. The following hypotheses are as follows:

H1: Micro finance institutions in Yemen are inefficient in terms of loan officer productivity.

$\mathrm{H} 2$ : Micro finance institutions in Yemen are inefficient in terms of Operational SelfSufficiency.

\section{Research Methodology}

After careful investigation and reading the review of literature. The researcher use empirical method as it is suitable for this study. The research relies on the use of the deductive method. The sample of the study was 11 microfinance institutions in Yemen representing the most population of the study. The data collected was based on both primary and secondary data. The primary data was collected through questionnaire, interviews. While the secondary data was collected from books, journals, magazines, microfinance institutions websites, etc.

\subsection{Research Design}

A research design was devised in a more traditional fashion specifying the research strategy. The research strategy will use the multi- methods approach to dig in and gather more information about the efficiency of Microfinance Institutions. The growth of Microfinance institutions is phenomenal as it is being reflected by the entry of new microfinance institutions into the market. However, the growth of MFIs industry is linked with successful implementation of good performance of microfinance institutions.

The following steps were done in order to make research design successful.

- Sampling criteria,

- Data collection,

- Data analysis.

\subsection{Sample of the Study}

The sample procedure used in the questionnaire is non-probability sampling due to the nature of data available. The use convenience sampling is made; as the questionnaires have been submitted by hand and also sent by email to senior MFIs professionals. The sample size for the questionnaire was 11 MFIs located in 4 governorates (Al- Amanah, Sana'a, Aden and Hadramaut) which represent 78 percent of all micro finance institutions in Yemen. The researcher approached General Managers, Branch Managers, Loan Officers, and Finance Managers. 
Table 3. Sample size of micro finance institutions in Yemen

\begin{tabular}{|c|l|c|c|c|c|}
\hline No. & \multicolumn{1}{|c|}{ MFIs } & Population & $\begin{array}{c}\text { Sample of } \\
\text { the Study }\end{array}$ & $\begin{array}{c}\text { No. of } \\
\text { Respondents }\end{array}$ & $\begin{array}{c}\text { Total No. of } \\
\text { Respondent }\end{array}$ \\
\hline 1. & Al-Amal MF Bank & 12 & 5 & 3 & 15 \\
\hline 2. & $\begin{array}{l}\text { Cooperative and Agricultural } \\
\text { Credit Bank }\end{array}$ & 33 & 12 & 3 & 36 \\
\hline 3. & Al-Tadhamon MF Program & 11 & 4 & 3 & 12 \\
\hline 4. & Al-Kuraimi Islamic MF Bank & 61 & 10 & 3 & 30 \\
\hline 5. & Saba Islamic Bank & 14 & 6 & 3 & 18 \\
\hline 6. & Aden MF Foundation & 5 & 2 & 3 & 6 \\
\hline 7. & National MF Foundation & 13 & 5 & 3 & 15 \\
\hline 8. & Nama MF Program & 4 & 2 & 3 & 6 \\
\hline 9. & Sana'a MF Program (Azal) & 5 & 2 & 3 & 6 \\
\hline 10. & $\begin{array}{l}\text { Wadi Hadramaut for Credit and } \\
\text { Saving Program }\end{array}$ & 2 & 2 & 3 & 6 \\
\hline 11. & $\begin{array}{l}\text { Small Enterprises Development } \\
\text { Fund }\end{array}$ & 7 & 3 & 3 & 159 \\
\hline & Total & 167 & & & \\
\hline
\end{tabular}

Source: Author. Primary Data. December 2015.

\subsection{Data Collection}

The data of the study was collected in two ways: primary data and secondary data. The primary data was collected through questionnaire, open ended interview. While the secondary data was collected from MFIs Annual reports, Yemen Microfinance Network (YMN), Social Fund for Development (SFD) Annual reports, Microfinance Magazine, reviewed literature, etc.

\section{Data Analysis}

The researcher also used Tables, Graphs, Charts to describe the performance of MFIs based on those answers in order to find out the weaknesses and strengths. The researcher analyzed the efficiency of microfinance institutions in Yemen based on Philippine Microfinance Standards, Micro Rate And Inter- American Development Bank.

Table 4. Efficiency analysis

\begin{tabular}{|c|c|c|c|}
\hline Area & Indicator & Definition/Ratio & Standard \\
\hline \multicolumn{4}{|c|}{ EFFICIENCY } \\
\hline 1. & $\begin{array}{l}\text { Loan Officer } \\
\text { Productivity }\end{array}$ & $\begin{array}{l}\text { Number of Active Borrowers } \\
\text { Number of Loan Officers }\end{array}$ & $\begin{array}{l}\text { Group }-\geq \text { to } 300 \\
\text { Individual }-\geq \text { to } 150\end{array}$ \\
\hline 2. & $\begin{array}{l}\text { Operational } \\
\text { Self- } \\
\text { Sufficiency }\end{array}$ & $\begin{array}{l}\text { Interest Income from Loans }+ \text { Service Fees } \\
+ \text { Filing Fees + Fines, Penalties, Surcharges } \div \\
\text { Financing Costs + Administrative Costs } \\
\text { (Direct \& Indirect costs) }\end{array}$ & $\geq 120 \%$ \\
\hline
\end{tabular}

Source: Philippine Microfinance Standards, 2007. 
9.1 Analyzing the Efficiency of Micro Finance Institutions in Yemen with Regard to Loan Officer Productivity

Based on Philippine Micro finance Standards, Micro Rate and American- Inter Development Bank, the researcher analyzed the efficiency of Micro Finance Institutions in Yemen.

Table 5. Loan officer productivity of MFIs in Yemen as December, 2014

\begin{tabular}{|c|l|c|}
\hline Sr. No. & \multicolumn{1}{|c|}{ Microfinance Institutions } & $\begin{array}{c}\text { Loan Officer Productivity } \\
\text { Greater than or equal to 300 }\end{array}$ \\
\hline 1. & Al-Amal Microfinance Bank & 300.14 \\
\hline 2. & National Microfinance Foundation & 236.91 \\
\hline 3. & Aden Microfinance Foundation & 327.93 \\
\hline 4. & Nama Microfinance Program & 128.32 \\
\hline 5. & Azal Microfinance Program & 128.57 \\
\hline 6. & Wadi Hadramaut for Lending and Saving Program & 310.75 \\
\hline 7. & Al-Kuraimi Islamic Microfinance Bank & 95.67 \\
\hline 8 & Al-Tadhamon Islamic Microfinance Bank & 80.46 \\
\hline 9. & Cooperative \& Agricultural Credit Bank & N.A. \\
\hline 10. & Saba Islamic Bank & N.A. \\
\hline 11. & Small Enterprise Development Fund & 266.76 \\
\hline & Mean & 208.39 \\
\hline
\end{tabular}

Source: Primary Data.

It is observed in Table 5 that the general standard for the efficiency of MFI in terms of loan officer productivity is greater than or equal to 300. It has been analyzed that Aden MF Foundation by 327.93 while Wadi Hadramuat MF Program by 310.75, and Al-Amal MF Bank by 300.14. It has been analyzed that AlKuraimi Islamic Microfinance Bank respond by 95.67, Al-Tadhamon Islamic Microfinance Bank respond by 80.46 , Nama Microfinance Program respond by 128.32, while Azal Microfinance Program respond by 128.57 and Small Enterprise development Fund respond by 266.76 which indicates that according the standards that other MFIs in Yemen are inefficient in terms of loan officer productivity. And two micro finance institutions do not give or disclose their financial reports or annual reports. The Mean was 208.39 which indicate that MFIs in Yemen are inefficient in terms of loan officer productivity.

9.2 Analyzing the Efficiency of Micro Finance Institutions in Yemen with Regard to Operational Self-Sufficiency

The general standard for evaluating the efficiency of micro finance institutions in terms of operational Self-Sufficiency is greater than 120 percent. 
Table 6. Operational self-sufficiency of MFIs in Yemen as December, 2014

\begin{tabular}{|c|l|c|}
\hline Sr. No. & \multicolumn{1}{|c|}{ MFI } & $\begin{array}{c}\text { Operational Self-Sufficiency } \\
\text { greater than } 120 \%\end{array}$ \\
\hline 1. & Al-Amal MF Bank & $260 \%$ \\
\hline 2. & National MF Foundation & $120 \%$ \\
\hline 3. & Aden MF Foundation & $192 \%$ \\
\hline 4. & Nama MF Program & $112 \%$ \\
\hline 5. & Azal MF Program & $93 \%$ \\
\hline 6. & Wadi Hadramaut for Lending and Saving Program & $144 \%$ \\
\hline 7. & Al-Kuraimi Islamic MF Bank & $96 \%$ \\
\hline 8 & Al-Tadhamon Islamic MF Bank & $112 \%$ \\
\hline 9. & CAAC Bank & N.A. \\
\hline 10. & Saba Islamic Bank & N.A. \\
\hline 11. & Small Enterprise Development Fund & $85.38 \%$ \\
\hline & Mean & 134.93 \\
\hline
\end{tabular}

Source: Primary Data.

It is observed in Table 6 that most microfinance institutions in Yemen are inefficient in terms of operational self- sufficiency. Except Al-Amal Micro finance Bank, Aden MF Foundation, and Wadi Hadramuat MF Program. The general standard for the efficiency of MFI in terms of operational self- sufficiency is greater than $120 \%$. According to the analysis done based on the reports from MFIs in Yemen. It is noticed that Al-Amal MF Bank has 260\%. While Aden MF Foundation has 192\% and Wadi Hadramaut MF Program has 144\%. It has been reported that National MF Foundation has $120 \%$. On the other hand, It has been analyzed that AlKuraimi Islamic Microfinance Bank respond by 96 percent, Al-Tadhamon Islamic Microfinance Bank respond by 112 percent, Nama Microfinance Program respond by 112 percent, while Azal Microfinance Program respond by 93 percent, and Small Enterprise development Fund respond by 85.38 percent which indicates that according the standards that other MFIs in Yemen are inefficient in terms of Operational Self- Sufficiency. The mean was 134.9 which indicate that MFIs are inefficient in terms of operational self-sufficiency.

\section{Findings of the Study}

The major Findings of this study regarding the efficiency are as follows:

1) Most Microfinance institutions in Yemen are less efficient in terms of loan officer productivity except Aden MF Foundation, Wadi Hadramuat MF Program and Al-Amal Micro finance Bank. The general standard for the efficiency of MFI in terms of loan officer productivity is greater than or equal to $300 \%$. It has been analyzed that Aden MF Foundation by 327.93 while Wadi Hadramuat MF Program by 310.75 , and Al-Amal MF Bank by $300.14 \%$. It has 
been analyzed according the standards that other microfinance institutions in Yemen are less efficient in terms of loan officer productivity. And two micro finance institutions do not give or disclose their financial reports or annual reports.

2) Most Microfinance institutions in Yemen are less efficient in terms of operational self- sufficiency. Except Al-Amal Micro finance Bank, Aden MF Foundation, Wadi Hadramuat MF Program. The general standard for the efficiency of MFI in terms of operational self- sufficiency is greater than $120 \%$. According to the analysis done based on the reports from microfinance institutions in Yemen. It is noticed that Al-Amal MF Bank has 260\%, while Aden MF Foundation has $192 \%$ and Wadi Hadramaut MF Program has $144 \%$. It has been analyzed that National MF Foundation has $120 \%$. It has been also analysed that other micro finance institutions in Yemen has less than $120 \%$. And two micro finance institutions do not give or disclose their financial reports or annual reports.

\section{Suggestions}

The main important suggestions made by the researcher based on the findings of the study are as follows:

1) It is suggested that microfinance institutions should increase the institutional capacity building and development.

2) It is suggested that microfinance institutions should implement a strategic plan for expansion and diversification of financial products and services supplied to SMEs.

3) Microfinance institutions should provide proper training to their loan officers so that they can perform their work very well.

4) It is also necessary that microfinance institutions should enhance the role of Research and Development.

5) Microfinance institutions should also enhance the role of performance management in order to strengthen the overall organizational performance.

6) It is also suggested that microfinance institutions should also maximize operational self-sufficiency as possible.

7) It is also suggested that microfinance institutions should increase operational self- sufficiency through providing more loans with less operational costs.

8) Government should take its responsibility by supporting microfinance institutions financially and technically at least to reach Operational SelfSufficiency, Efficiency, Financial Self-Sufficiency and expand outreach.

9) It is also suggested that microfinance institutions should enhance the loan officer's efficiency and productivity. 


\section{$\Lambda$ Macrothink}

\section{Conclusion}

Microfinance has gained a universal recognition as an important tool for reducing poverty in many developing countries. Performance concept relating to MFIs is a vital and crucial issue for many reasons such as: to ensure donors or/investors effective and efficient utilization of billions of dollars invested in MF programs also help regulators in controlling and monitoring the MFIs, stating that inefficient MFIs represents a main constraint on the development of the microfinance industry. In this study, microfinance institutions are inefficient in terms of loan officer productivity and operational self-sufficiency. The study presented some important suggestions to strengthen \& improve the efficiency of microfinance institutions in the country.

\section{Acknowledgements}

This research was financed by the Ministry of Higher Education and Scientific Research, Yemen. I am so grateful to Dr. Abdulaziz Al-Shoaibi, Deputy Minister for Higher Education \& Scientific Research. I am also very grateful to Mr. Moath AlShihapy, Executive Officer, Heritage \& Cultural Development Fund, Ministry of Culture, Yemen. I am also very grateful to all those who help me and provide me with the necessary information to make this study more valuable and rich.

\section{References}

Armendáriz, B., \& Labie, M., (2011). The Handbook of Microfinance. London, Singapore: World Scientific Publishing. https://doi.org/10.1142/7645

Ganka, D. (2010). Financial sustainability of rural microfinance institutions in Tanzania. Retrieved from http://scholar.mzumbe.ac.tz/bitstream/handle/11192/533/Ganka_Daniel_Nyamsogoro_2010.p df? sequence $=1$

Hermes, N., Lensink, R., \& Meesters, A. (2014). Outreach and Efficiency of Microfinance Institutions. Retrieved on $18^{\text {th }}$ June 2014 from https://www.rug.nl/research/portal/files/2745271/08002.pdf

Morduch, J. (2000). The Microfinance schism. World Development, 28, 617-629. https://doi.org/10.1016/S0305-750X(99)00151-5

Nawaz, A. (2010). Efficiency and Productivity of Microfinance: Incorporating the Role of Subsidies. Research Institute in Management Sciences.

Nghiem, H. S., Tim, C., \& Prasada, R. (2007). The Efficiency of Microfinance Institutions In Vietnam: Evidence From NGO Schemes in the North and the Central Regions. Retrieved on $22^{\text {nd }} \quad$ June $2016 \quad$ from https://www.researchgate.net/publication/43455840_The_efficiency_of_microfinance_in_Vie tnam_Evidence_from_NGO_schemes_in_the_north_and_the_central_regions

Philippine Microfinance Standards. (2002). Regulatory Framework for Microfinance 


\section{Macrothink}

World Journal of Business and Management

ISSN 2377-4622 2018, Vol. 4, No. 2

Institutions $\quad($ MFIs $)$. Retrieved on $17^{\text {th }} \quad$ May 2014 from http://www.microfinancecouncil.org/wp-content/uploads/2011/06/Performance-Standards-for -MFIs.pdf

Qayyum, A., \& Munir, A. (2015). Efficiency and Sustainability of Micro Finance Institutions in South Asia. Retrieved on $18^{\text {th }}$ June, 2015 from http://www.sanei-network.net/uploads/research/efficiency-and-sustainability-of-micro-financ e-institutions-in-south-asia1464171189.pdf

Woller, G. (2000). Reassessing the Financial viability of Village Banking: Past Performance and Future Prospects. The East Asian Journal of Business Management, 3(1), 5-16.

Woller, G., \& Schreiner, M. (2002). Poverty lending, financial self-sufficiency, and the six aspects of outreach. Retrieved from https://www.researchgate.net/publication/265233328_POVERTY_LENDING_FINANCIAL_ SELF-SUFFICIENCY_AND_THE_SIX_ASPECTS_OF_OUTREACH

Yin, R. K. (1994). Case Study Research, Design and Methods (2nd ed.). Newbury Park: Sage Publications.

\section{Copyright Disclaimer}

Copyright for this article is retained by the author(s), with first publication rights granted to the journal.

This is an open-access article distributed under the terms and conditions of the Creative Commons Attribution license (http://creativecommons.org/licenses/by/3.0/). 